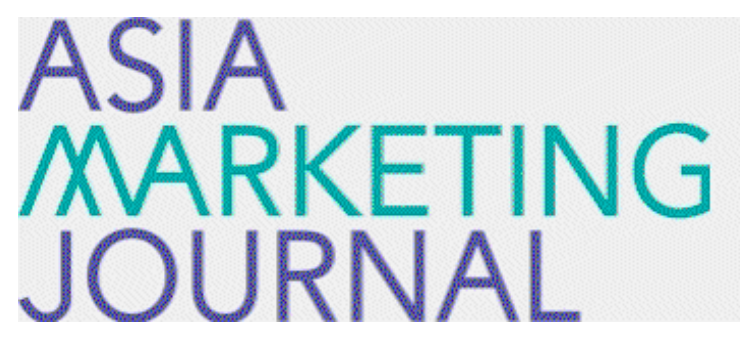

ASIA MARKETING JOURNAL

Volume 4 | Issue 4

Article 2

$12-1-2002$

\title{
마케팅성과모델을 이용한 제조기업과 서비스기업의 비교
}

Sung Joon Yoon

Gai Bong Choi

Follow this and additional works at: https://amj.kma.re.kr/journal

Part of the Marketing Commons

\section{Recommended Citation}

Yoon, Sung Joon and Choi, Gai Bong (2002) "마케팅성과모델을 이룡한 제조기업과 서비스기업의 비교," Asia Marketing Journal: Vol. 4 : Iss. 4 , Article 2.

Available at: https://doi.org/10.53728/2765-6500.1095

This Article is brought to you for free and open access by Asia Marketing Journal. It has been accepted for inclusion in Asia Marketing Journal by an authorized editor of Asia Marketing Journal. 


\title{
마케텅성과모델을 이용한 제조기업과 서비스기업의 비교*
}

\section{A Comparison of Manufacturing Firms and Service Firms Using a Marketing Performance Evaluation Model}

\author{
윤성준(경기대학교 경영학부 부교수) \\ sjyoonekyonggi.ac.kr \\ 최계봉(경기대학교 경영학부 교수) \\ gbchoi kyonggi ac. kr
}

본 연구는 마케팅성과에 대한 Kotler의 접근법을 원용하여 한국의 대표적인 제조기업과 서비스 기업들의 마케팅 성과에 영향을 주는 요인들을 발견하고 경영 시사점을 제시하기 위한 모델을 개발하였다. 재조 분야에서 10 개 기업, 서비스 분야에서 9 개 기업을 각각 선정하여 전체 19 개 기업의 마케팅 성과의 수준을 평가해 보았다. 확인요인분석 졀과 제조기업의 마케텅 성과요인으로는 마케팅 인력, 마케팅 조직, 마케텅 전략이 추출되었고 서비스기업의 요인으로는 마케팅 인력, 마케팅 정보, 고객지향성, 마케팅 전략이 추출되었다.

5 개의 마케팅성과요인과 제품력, 유통력, 판촉력, 가격력으로 구성된 마케팅역량, 그리고 고객만족 간의 관계를 규명할 목적으로 구조방정식모형을 구축하고 관계들에 관한 가설뜰을 검중하였다. 요인분석결과 재조기업은 마케팅인력, 마케팅 조직, 마케팅 전략의 새 요인이 유의한 요인으로 나타넜으나, 서비스 기업에서는 마케팅 인력, 마케팅 정보, 고객지향성, 마케팅 전략의 4 요인이 유의하게 나타넜다. 각 요인의 평균치 분석결과, 서비스기업이 제조기업에 비해 마케팅성과 영향요인, 마케팅역량과 고객만족에서 모두 우세하게 나타났다.

\footnotetext{
* 논문접수 : 02.09 개제확정 : 03.02

본문의 수정에 도움율 주신 익명의 심사위원닙들에게 감사률 드립니다.
} 


\section{1. 서론}

현대의 경쟁 환경은 기업의 성패여부를 성공적인 마케팅의 실행에서 찾도록 강요하고 있다. 효과적인 마케팅의 실행은 전략기흭과 영업력의 원동력이 되고 있으며 조직 전반적인 목표달성의 결정적 요인으로 간주되고 있다. 점중하는 경영환경의 역동성과 증가하는 불확실성으로 말미암아 기업 경영자돌은 기업내외의 마케팅 활동의 효과의 측정과 성과에 대한 예측가능성올 높이기 위해 많은 노력을 경주해 왔다. 이러한 배경 하에서 마케팅성과모델은 지금까지 많은 연구자와 실무자들의 주의와 관심을 받아왔다 (Norburn 외 1990; Lai 외 1992; Ghosh 외 1993; Dunn 외 1994; Yukselen 1997; Sin \& Tse 2000; Appiah-Adu 외 2001). 일반적으로 이들 연구자들은 마케텅성과가 마케팅 개념의 수용과 실행, 이라는 양면적 개넘으로 구성되어 있다고 보았다.

1977년 Kotler에 의해 처음 소개된 마케팅성과모델은 세가지 특성을 지닌다고 평가될 수 있다. 첫째, 마케팀 성과률 (1)고객 철학, (2)통합적 마캐팅 조직, (3)적절한 마케팅 정보. (4)전략적 지향성, (5)활동의 효율성의 다섯개 요인으로 정의하였다. 또한 매출액과 이익과 같은 결과지향적 성과변수만으로는 도출하기 어려운 마케팅의 실행지향적 즉, 과정지햠적 개념으로 보았다 (Kotler 1988). 둘째, 위의 다섯개 요인은 태도에 근거하지 않고 실천적이고 과업 지향적인 마케팅 능력에 근거하고 있다. 즉, 이 모델은 마케팅 관리자가 각 시장의 서로 다른 욕구에 대응하여 차별화된 제품의 제공 등의 계획을 실천하는 정도에 초점을 두며 공급자, 채널, 경쟁자, 소비자, 환경 등을 포괄하는 마케팅시스템의 홍체적 관점을 취하고 있다. 세째, 마케팅성과는 시장정보률 하나의 요소로 반영하는 마케팅 톻제 메커니즘이라는 광범위한 틀 안에서 현장의 욕구를 만족시키기 위한 기업의 수행력을 반영한다고 볼 수 있다.

마케텅성과의 개넘은 지속적 성장, 경쟁우와, 그리고 마케팅 지향성과 같은 조직 변수들과 연관하여 논의되어져 왔다 (Kotler 1977; Norburn 외 1990). 이와 동일한 맥락에서 몇몇 연구자들은 서비스 기업이 갖고 있는 마케팅 문화와 마케팅성과와의 관계에 대해서 규명하려 하였다 (Webster 1995; Sin and Tse 2000; Appiah-Adu 2001). 그중 몇 연구는 Peters 와 Waterman (1982)이 주장한 미국의 우수한 기업의 푱통적 특징으로 지적된 3개 변수-1) 소비자와의 친근성, 2) 기업가치관, 3) 시장지향성--을 사용하였다 (Norburn 외 1990; Sin and Tse 2000). 그들 연구결과는 모두가 서비스산업에서의 마케팅성과는 사업성과에 정의 유의한 영향을 미친다는 것을 보고하였다. Webster $(1933,1995)$ 는 마케팅 성과를 서비스 품질, 대인관계, 판매과업, 조직력, 내부 의사소통, 그리고 혁신성과 같은 마케팅 문화 요인과 연계 시켜 서비스기업 내에서 두 개념의 유의한 관계를 규명하였다. 또한 다룐 연구는 금윰서비스산업에서 마케팅성과가 고객 유지, 판매증가, 수익과 유의한 관계가 있음을 규명하였다 (Appiah-Adu 외 2001).

본 연구는 두가지 목적을 갖고 있다. 첫째로, Kotler의 마케팅성과모델을 기본으로 한 수정모델에 입각하여 한국의 대표적인 제조기업과 서비스기업 간의 차이를 비교, 분석하여 본다. 특히 마케팅성과의 5 개 요인의 상대적 중요성을 요인분석을 퉁해 검증하고 제조기업과 서비스기업에 관한 마케팅성과측정모델을 개발한다. 또한 이 모델의 성과측정요인으로 마케텅 막스의 성공적 실행을 평가할 수 있는 마케팅역량개념을 개발하고 검중한다.

둘쩨로, 마케팅성과의 5 개 영향요인을 독립변수로 하고 마케팅역량과 고객만족을 
결과변수로 하는 마케팅 성과모델을 정립하고 구조방정식모형을 사용하여 그 관계의 유의성을 검증한다. 재조기업과 서비스기업간의 성과에 미치는 마케팅 성과 요인을 추출함으로써 제조기업과 서비스기업의 마케팅 자원의 효과적 활용에 대한 중요한 근기률 제공하고 이에 대한 경영시사점을 제공하는데 이 연구의 목적이 있다.

\section{2. 문헌고찰}

기존 연구둘은 마케팅 성과의 결과변수로써 주로 매출액, 이익률, ROI 등과 같은 계략적 변수를 사용하였으나 (Webster 1995; Sin and Tse 2000; Appiah-Adu 2001). 이 같은 성과 변수들온 과업의 결과적 성격을 반영하고 매개역할을 하는 과정지향적 요인들을 간과 할 수 있다는 점에서 한계를 갖고 있다. 본 연구에서는 마케팅역량이라는 개념을 사용하여 과업 지향적인 마케팅믹스 변수들을 중심으로 현재의 마케텅조직에서 진행되고 있는 마캐팅활동의 잠재적 역량에 초점을 둔다. 본 연구의 또 다른 차이점은 고객만족개넎을 연구모델에 포함시켜 조직의 마케팅 역량이 기업의 자체 조사에 의한 고객만족점수애 어떤 영향을 미치는가률 본 것이다. 본 연구는 마케팅 역량이라는 조직의 과업지향적 잠재력을 결과변수로 하여 기존의 마케팅성과요인과 결합하여 궁극적인 고객만족에 미치는 영햐을 보여준다는 점에서 기존의 결과 지향적인 마케팅성과를 이용한 연구들과는 구별된다고 볼 수 있다.

지금까지의 연구들은 주로 서비스기업에서의 마케팅성과에 주로 초점을 두었으며 (Kotler 1977; Norburn 외 1990; Webster 1995; Sin and Tse 2000; Appiah-Adu 2001).제조기업과 서비스기업간의 마케팅 성과를 비교 측정한 연구는 찾아보기 어렵다. 경영의 다각화와 고객위주의 경영으로 대변되는 현대의 기업한경에서는 제조기업과 서비스기업의 구분이 점차 회박해 짐에 따라 산업간의 강점예 입각한 새로운 하이브리드 경영의 중요성은 커지고 있다. 이런 시점에서 서비스 지향적인 기업과 제조 지향적인 기업의 성과에 유의한 영향을 미치는 요인을 발견하는 것은 각각의 산업의 특성을 이해하는데 도움을 줄뿐만 아나라 제조지향적 (또는 효율성 위주의) 서비스기업 또는 서비스지향적 제조기업과 같은 복합적 (hybrid), 유연적 (flexible), 충체적 (holistic) 조직의 특성을 도출하기 위한 유용한 경영전랴적 정보를 제공해 줄 수 있다.

\section{1 제조기업과 서비스기업의 차이점}

서비스제품은 그 특성상 제조제품과는 판이한 점을 갖는다. 무형성(intangibility), 생산과 소비의 동시성, 서비스의 이질성 (heterogeneity), 그리고 소멸성(perishability)이 그 차별적 튝성이라고 볼 수 있다 (Zeithaml 외 1985). 이유재 (1997) 는 서비스 제품의 일반적 특성으로 1) 상품의 성격이 다르고, 2) 생산과정에 고객이 참여하고, 3) 사랍들의 상품의 일부분이고, 4) 품질의 통제가 어렵고, 5) 제고가 없으며, 6) 시간요인이 중요하고, 7) 유통경로가 다르다는 점을 들었다. 또한 마케팅의 특성상 서비스기업의 경영자들이 제조기업보다 마케팅적 사고의 적용범위가 좁을 수 있고, 서비스기업은 대고객 접쳑이 이루어져야 하므로 마케팅관리자가 서비스 제공 종업원과의 접근이 용이한 조직구조가 필요하다는 점에서 제조기업과 다를 수 있다 (이유재 1997). 
마케팅기능에 있어서 생산과 소비가 분리되는 제조기업에서는 생산부서와 고객이 직접적인 접촉은 없지만, 생산과 소비가 동시에 일어나는 서비스기업에서는 마케팅 부서가 생산부서가 담당하는 인력과 시설, 절차 등과 함께 관여하여야 하므로 생산부서와의 긴밀한 협조가 요구될 것이다.

인적자원의 관리에 있어서는 고객과 종업원의 접촉과 상호작용(interaction) 이 빈번한 서비스업에서는 종업원의 고객지향적 사고와 노하우, 그리고 물리적 시설의 효율적 운영이 기업의 이미지와 평판에 직접적인 영향을 미칠 수 있으므로 제조 기업보다 효과적인 인적자원의 관리가 팔요하뎌 서비스 교육과 훈련에 더 많은 투자가 요구될 것이다. 서비스기업에서는 제조기업과 마찬가지로 교객지향성이 중요하계 된다. 그러나 고객만족의 직접적인 정책의 반영 또는 인사의 반영도는 서비스기업에서 좀더 가시적이고 실체적일 수 있다. 예냐하면 서비스기업에서는 생산지향적 사고보다는 고객니즈에 신속히 대옹할 수 있는 고객지향적사고가 우선되어야 하기 때문이다.

국내외적으로 제조기업과 생산기업간의 차이점을 조사한 연구는 극히 드물다. 이는: 두개의 산업이 판이하게 차별되기 때문이라고도 볼 수 있다. 한 연구는 9개 국가의 2,419 개의 제조기업과 서비스기업에서의 선점적 우위 (pioneering advantage)를 비교하였는데 제조기업 경영자들이 서비스기업 경영자들보다 선점에 대한 위험을 더 유의하게 중시한다는: 것을 발견하였으며, 선점의 비용과 차별화에 따른 우위는 서비스 기업보다는 제조기업에 있어서 더 중요하다는 깃을 발견하였다 (Song 외 1999). 그 외의 연구로는 재조기업과 서비스기업간의 생산성중가 또는 고용률과 같은 거시적 지표의 차이를 조사한 것과 (Kozicki 1997), 제조와 서비스 부문간의 능력과 성과에 기준한 보수의 차이를 인적자원관리 차원에서 조사한 연구가 있올 따름이다 (Jahja \& Kleiner 1997). 품질관리에 있어서도 몇 개의 관롄 연구가 실시되었는데 한 면구는 미국의 제조기업과 서비스기업의 중역들을 대상으로 품잘관리프로그램의 사용과 혜택에 대해 조사하였으며 그 결과 재조기업에서 서비스기업보다 더 높은 품질관리시스템이 유지되었고 품질이 경영환경에 영향을 받는다는 것을 발견하였다 (Gowen III \& Tallon 1999). 유사한 연구로 싱가포르의 서비스업과 제조업의 선두기업간의 전사적 품질관리 (TQM)를 비교한 연구도 있다 $(\operatorname{Kim} 2000)$.

\section{2 마케팅성과의 기존 측정모델}

마케팅 할동들의 성과률 분석하기 위해 개발된 가존 모델들을 비교해 보면 다음 표와 같다.

<표 1> 기존 마케팅성과 측정모델

\begin{tabular}{|c|c|c|c|}
\hline 모델 & 개발자 & 핵심 개념 요인 & 모델의 특성 \\
\hline $\begin{array}{c}\text { Marketing } \\
\text { Effectiveness }\end{array}$ & Kotler (1977) & $\begin{array}{l}\text { - 소비자 철학 } \\
\text { - 통합된 마케텅 조직 } \\
\text { - 마캐팅 정보 } \\
\text { - 전략적 지향성 } \\
\text { - 활동의 효율성 }\end{array}$ & $\begin{array}{l}\text { - 과정지향적, 과업지향적 특성 } \\
\text { - 기업간 마켸팅 성과 비교기준 제공 } \\
\text { - 고객지향적 믁성 포합 }\end{array}$ \\
\hline
\end{tabular}




\begin{tabular}{|c|c|c|c|}
\hline $\begin{array}{c}\text { Market } \\
\text { Orientation }\end{array}$ & $\begin{array}{l}\text { Jaworski and } \\
\text { Kohli (1993) }\end{array}$ & $\begin{array}{l}\text { - 최고경영자 } \\
\text { - 부서간 역학관계 } \\
\text { - 조직 시스텀 }\end{array}$ & $\begin{array}{l}\text { - 정보의 창출, 배분, 반응에 초점을 둠 } \\
\text { - 마케팅 조직적 역학성에 중점왈 둠 } \\
\text { - 외부환경의 영향력을 평가함 }\end{array}$ \\
\hline $\begin{array}{l}\text { Marketing } \\
\text { Audit }\end{array}$ & $\begin{array}{l}\text { Kotler, Gregor, } \\
\text { Rogers (1984) }\end{array}$ & $\begin{array}{l}\text { - 마케팅환경 } \\
\text { - 마케팅전략 } \\
\text { - 마케팅조직 } \\
\text { - 마케팅시스템 } \\
\text { - 마케팅생산성 } \\
\text { - 마케텅기능 }\end{array}$ & $\begin{array}{l}\text { - 문제발견, 기희의 포착, 기휙수립 } \\
\text { - 공식적, 비역동적 모델 } \\
\text { - 기업간 마케팅 성과 비교기준 제공 } \\
\text { - 평가률 통한 행동계혁 제시 }\end{array}$ \\
\hline $\begin{array}{l}\text { Marketing } \\
\text { Excellence } \\
\text { Review }\end{array}$ & Kotler(1994) & $\begin{array}{l}\text { Best practice 애 대비한 } \\
\text { 우수, 양호, 불량 }\end{array}$ & $\begin{array}{l}\text { - 마케팅성과의 벤치 마킹 모델 } \\
\text { - 성과의 상대적 평가로 인한 기준 } \\
\text { 설정의 위험 }\end{array}$ \\
\hline $\begin{array}{l}\text { Marketing } \\
\text { Checklist }\end{array}$ & $\begin{array}{l}\text { Wilson (1993) } \\
\text { Sparling } \\
\text { (1992) }\end{array}$ & $\begin{array}{l}\text { - 마켸팅 전력과 계혁 } \\
\text { - 제품/서비스의 범위 } \\
\text { - 마캐팅과 서비스 } \\
\text { - 기업실적 } \\
\text { - 수출 마케팅 } \\
\text { - 마케텅정보시스템 } \\
\text { 외 충 } 24 \text { 문항 }\end{array}$ & $\begin{array}{l}\text { - 정형화로 인한 반복성 혀피 } \\
\text { - 벤치마킹을 이용한 기업성과 축정 } \\
\text { - 에외적 중요평가항목의 처리 볼분명 }\end{array}$ \\
\hline $\begin{array}{l}\text { Marketing } \\
\text { Innovation }\end{array}$ & $\begin{array}{c}\text { 일본관리협회 } \\
\text { 컨설팅(JMAC, } \\
\text { 1996) }\end{array}$ & $\begin{array}{l}\text { - 욕구 표악 } \\
\text { - 아이디어 유출 } \\
\text { - 아이디어의 유통 } \\
\text { - 프로그램밍(전략화) } \\
\text { - 영업관리력 }\end{array}$ & $\begin{array}{l}\text { - 경영혁신올 위한 마케텅 현상펴악 } \\
\text { - 평가분야 간 상호관련성 결여 } \\
\text { - 이른적 배경 결여 }\end{array}$ \\
\hline
\end{tabular}

위의 표에서 주목할 사실은 Kotler의 마케팅성과모델을 제외하고는 모두 고객지향:적 톡성이 결여되어있다는 점이다. 외부한경적 요인을 포함한 모델은 시장지향성모델과 마케텅 감사에 불과하다. 마케팅 성과와 관련된 모델둘 거의 모두가 기업내부적 자원의 활용정도와 그 성과에만 역점을 두었음을 알 수 있다. 즉, 대부분의 모델둘이 마케팅 전략, 마케팅 정보, 마케팅 조직과 관련한 내부지향적 관점에서 접근하고 있다. 그 이유로는 성과로서 접근할 수 있는 객관적 자료들이 외부환경 의존적(예: 고객성향의 변화)일 뿐만 아니라 외부적 자료의 신뢰성도 문제가 될 수 있기 때문이라고 해석할 수 있다. 시장지향성모델은 현재 또는 미래의 고객 니즈에 관한 시장정보를 조직적 차원에서 생성, 배분하고 이에 대한 반웅을 반영하는 것으로 보았다. 실중연구 결과 시장지향성은 종업원의 조직에 대한 충성도와 공동체 의식에 영향을 미치며 사업성과에도 중요한 영향력을 갖는다고 판명되었다 (Jaworski \& Kohli 1993). 이와 같이 시장지향성모델은 기업성과요인 외의 성과요인으로 종업원의 수행력과 단결력을 설정하였는데 이는 기업내의 조직력의 중요성을 반영한 것이라고 볼 수 있다. 


\section{3. 마케팅 성과모델의 개발}

본 연구에서 채택된 모델은 마켸팅 전문가들 (3명의 마케팅 박사와 3 명의 석사)과 10 개 기업 (5개 제조, 5 개 서비스 기업)의 마케팅 부서 임원들과의 인터뷰를 통한 자료수집과정을 거쳐 기존의 Kotler (1977)의 마케팅성과 모델을 수정 보완하였다. 모델 개발의 칫 과정으로써 전문가그룸이 주도하여 일차적으로 마케팅성과의 측정을 구성하는데 필요하다고 판단되는 많은 측정항목이 수집되었다. 수집된 항목에 대한 분류결과 항목들은 (1)고객지향성, (2)마케팅 조직, (3)마케팅 정보시스템, (4)마케팅 전략, (5)마케팅 인력의 다섯가지 요인들로 분류되었다. 마케팅성과의 기본 모델과 비교해 불 때, 수정된 모델의 주요 차이점은 기본 모델에서의 “활동의 효율성" 이 "마케팅인력"으로 대체된 것이다. 기 이유는 마케팅을 효과적으로 실행하는데 있어서 고급인력의 보유는 마케팅 성과에 매우 중요한 영향을 미칠 것이라고 전문가 그릅이 판단하였기 때문이다. <표 2>는 이들 각 차원들에 속하는 주요 항목들을 Kotler $(1977,1988)$ 가 사용한 마케텅성과모델과 바교하여 보여준다.

<표 2> Kotler의 마케팅성과모댈과 본 연구모델간의 구성요인 비교

\begin{tabular}{|c|c|c|c|}
\hline \multicolumn{2}{|c|}{ 마케팅성과 모델 } & \multicolumn{2}{|c|}{ 본 연구 모델 } \\
\hline 요인 & 구성요소 & 요인 & 구성요소 \\
\hline 고객 철학 & $\begin{array}{l}\text { 시장요구에의 반응 } \\
\text { 시장 세분화 전략 } \\
\text { 마케팅우선시 }\end{array}$ & 고객 지향성 & $\begin{array}{l}\mathrm{CS} \text { 업무의 중요도 } \\
\mathrm{CS} \text { 결과의 정책 반영도 } \\
\mathrm{CS} \text { 결과의 인사 반영도 }\end{array}$ \\
\hline $\begin{array}{c}\text { 톻합적 마케팅 } \\
\text { 조직 }\end{array}$ & $\begin{array}{l}\text { 마케텅통합과 조정 } \\
\text { 타 부서와의 시너지 } \\
\text { 신제품 개발 }\end{array}$ & 마케팅조직 & $\begin{array}{l}\text { 마케텅부서의 위상 } \\
\text { 마케팅조직의 조직력 } \\
\text { 타 부서와의 협동 }\end{array}$ \\
\hline $\begin{array}{c}\text { 적절한 마켸팅 } \\
\text { 정보 }\end{array}$ & $\begin{array}{l}\text { 마케팅리서치수행 } \\
\text { 시장에 대한 지식 } \\
\text { 비용대비 효과 }\end{array}$ & $\begin{array}{c}\text { 마케덩정보 } \\
\text { 시스템 }\end{array}$ & $\begin{array}{l}\text { 정보시스탬 접근성 } \\
\text { 정보시스탬 활용정도 } \\
\text { 타 부서와의 정보광유 }\end{array}$ \\
\hline 전략적 지향성 & $\begin{array}{l}\text { 마켸팅계헉의 공식성정도 } \\
\text { 마켸팅전략의 질 } \\
\text { 위기대옹 능력 }\end{array}$ & 마케팅전략 & $\begin{array}{l}\text { 마캐팅 중요성 인식 } \\
\text { 최고경영 충의 의지 } \\
\text { 전략의 체계화 }\end{array}$ \\
\hline 활동의 효율성 & $\begin{array}{l}\text { 마케팅사고의 하향식의사소통 } \\
\text { 마케팅자원의 효율성 } \\
\text { 불학실한 환경에의 대웅능력 }\end{array}$ & 마케팅인력 & $\begin{array}{l}\text { 마케팅 경협의 정도 } \\
\text { 마케팅 마인드 구비 } \\
\text { 마케텅 교육과 훈련 }\end{array}$ \\
\hline
\end{tabular}

\section{1 마케팅성과모델과 연구가설}

본 연구에서는 독립 변수인 마케팅성과요인과 결과 변수인 마케팅역량과 고객만족으로 구성된 새로운 마케팅성과모델을 구축하고 모델변수 간의 관계를 검증하기 위한 분석을 
위하여 아래 그림과 같은 기본모형을 개발하였다.

<그립 1> 기본 마케팅 성과모델

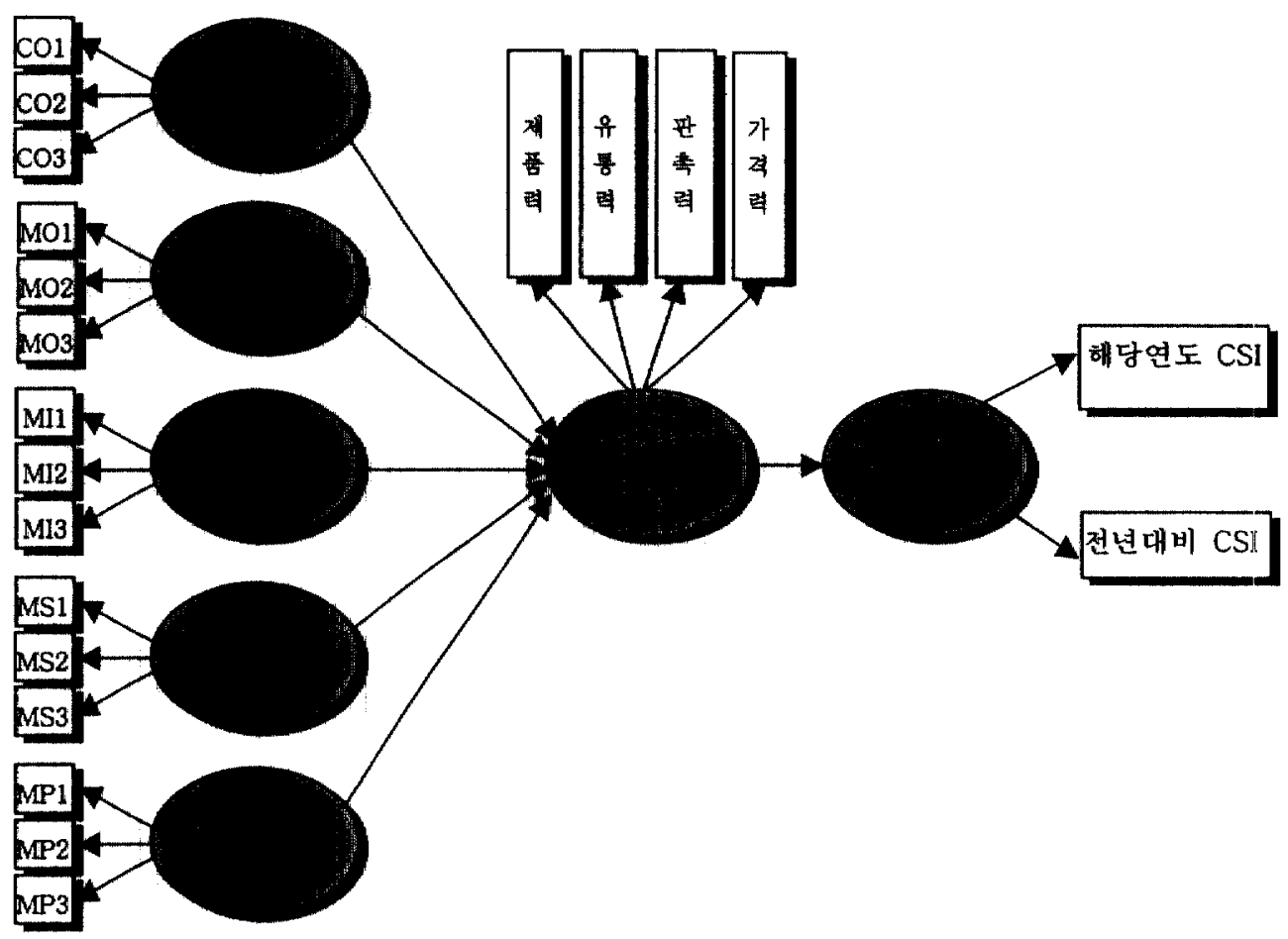

마케팅 성과요인들의 마케팅역량에 대한 영향에 대해 토론하기에 앞서, 마케팅역량(marketing capacity)의 조작적 정의에 대한 이해률 분명히 할 필요가 있다. 마케팅역량은 마케팅 믹스의 성공적 실행의 결과로 나타나는 총체적 마케팅조직의 집합적 능력" 이라고 연구자에 의해 정의되었고 본 연구에서는 제품력, 유퉁력, 판촉력, 가격력에 대한 총 18 개 문항으로 구성되었다. 다음은 마케팅 성과의 5개 영향요인 (고객 지항:성, 마케팅 조직, 마케팅 정보, 마케팅 전략, 마케팅 인력)에 대한 조작적 정의롤 설명하고 이들 요인과 마케팅역량 간의 관계, 그리고 마케텅역량과 고객만족에 대한 관계들을 연구가설로 정리한다.

\section{2 고객 지향성과 마케팅역량}

고객에 대한 지향성은 본 연구에서 고객만족 업무의 중요성과 고객만족 결과가 정책에 반영되는 정도, 그리고 그 결과가 인사에 반영되는 정도로쌔 정의되었다. 일반적으로 고격의 욕구에 대한 파악과 욕구충만을 위한 내부 조직 시스템이 구비되었다 함은 조직 구성원의 고객만족에 대한 노력과 보상의 상관관계를 인지하도록 만둘어 준다. 이와 같은 긍정적인 
상관관계의 인식은 조직 구성원으로 하여금 마케팅의 실행에 대한 자신감 뿐만 아니라 동기구축예 긍정적인 영향을 준다고 볼 수 있다. Narver 와 Slater (1990) 그리고 Day 와 Wensley (1988)는 시장지향성과 기업성과간의 관계률 규명하면서 고객지향성이 시장지향성의 한 구성변수로쌔 유의한 영향이 있음을 발견하였다. 또한 기업의 경쟁우위의 원천온 고객관점과 경쟁자 관점이고 이 관점돌이 균형적으로 발전되어야 한다고 기존 연구들온 주장하였다 (Kohli \& Jaworski 1990; Narver \& Slater 1990). Kotler (1988)는 고객지향적 기업 욘 새로운 기회를 발견하고 장기적으로 효과적인 전략을 수립하는데 필수적이라고 주장하였다. 결과적으로 이는 조직의 마케팅역량에 긍정적인 유의한 영향을 줄 것으로 가정되므호 다음과 같은 가설이 도출될 수 있다.

가설 1a: 제조기업의 고객지향성은 마케팅역량에 정의 유의한 영향을 미친다.

가설 $1 \mathrm{~b}$ : 서비스기업의 고객지향성은 마케텅역량에 정의 유의한 영향을 미친다.

\section{3 마케팅 조직과 마케팅역량}

마케팅 조직은 마케팅부서의 위상과 마켸팅 조직의 조직력, 그리고 타부서 와의 협력정도에 의해 정의되었다. 먼저 마케팅 부서가 기업전체 자원의 분배 또는 인력 양성에 있어서 우선적으로 고려될 경우 그 부서는 마케팅 업무의 추진력이 생기게 되고 이는 마케팅 전략의 실행에도 긍정적 영향을 줄 것이다. 마케팅부서의 전문성과 공식화에 따르는 조직력은 마케팅 전략의 수행시 대응력을 높여주고 체계적인 자원의 투입올 가능캐 하므코 결과적으로 이는 마케팅역량에 유의한 긍정적 영향을 줄 것이다. 기존연구를 보면 조직문화를 마케팅성과의 선행변수로 고려한 경우가 많았다 (Dunn 외 1985; Norburn 외 1990; Oosthuizen 1992; Desphande 외 1993). 이들 연구는 조직문화가 조직적 전략의 실행옳 위해 경영자들을 하나로 결속시키는 역할을 한다고 보았다. Parasuraman과 Deshpande (1984)는 조직의 집합적 문화가 기업의 마케팅 집행에 직접적인 영향올 주게 되므호 마케팅성과에 유의 하다고 결론지었다. 위와 같은 선행연구에 비추어 보아 다음과 같은 가설을 도출할 수 있다.

가셀 $2 \mathrm{a}$ : 제조기업의 마케팅 조직력은 마케팅역량에 정의 유의한 영향을 미친다.

가설 2b: 서비스기업의 마케텅 조직력은 마케텅역량에 정의 유의한 영향을 미친다.

\section{4 마케팅 정보와 마케팅역량}

마케팅 정보시스템에 대한 조작적 정의는 정보시스템의 접근 용이성과 마케팅 정보시스템의 활용정도, 그리고 타 부서와의 정보공유수준으로 구성되어진다. 마케팅 관련 기업내외의 정보률 수집하고 입력할 수 있는 권한과 의무의 부여는 언제 어디에서나 그 시스템에 접근 가능할 수 있음을 의미하며 이는 조직구성원의 정보력을 높이게 된다. 마케팅 정보시스템이 접근이 용이하게 되면 정보가공을 통한 정보의 부가가치를 높이는 기회가 많아지게 될 것이고 이는 시스템의 활용목적과 결과를 확대하는 결과률 가져오게 된다. 고객 정보를 타부서와의 정보공유가. 용이하게 될 경우 전사적인 정보관리가 가능하여짐으로써 제품별, 부서별로 분산되어있는 고객정보률 종합적으로 수집, 분석해서 
상호 연계하여 활용할 수 있는 고객정보망을 구축할 수 있다. 결과적으로 이것은 조직의 마케팅역량을 제고하는데 긍정적인 영향을 미칠 것이다. Kohli와 Jaworski (1990)는 시장지향성을 마케팅정보의 창출과 배분, 그리고 반웅의 세변수로 정의하였으며 많은 후속 연구듈이 시장지향성과 사업성과 간의 유의한 관계률 규명하였다 (전인수, 한재용 1994; 김용준, 김진수 1996; 건영철 1996; 이용기 외 1996; Jaworski \& Kohli 1993; Slater\& Narver 1994; Greenley 1995; Pelham \& Wilson 1996). 선행연구률 토대로 하여 다음과 같온 가설이 도출되었다.

가설 3a: 제조기업의 마케텅 정보시스텀은 마케팅역량에 정의 유의한 영향을 미친다.

가설 $3 \mathrm{~b}$ : 서비스기업의 마케팅 정보시스템은 마케팅역량에 정의 유의한 영향을 미친다.

\section{5 마케팅 전략과 마케팅역량}

마케팅 전략은 경영자들에 의한 마케팅 개념의 이해수준과 최고경영충의 의지, 그리고 마케팅전략의 체계화로 조작적 정의되었다. 마케팅 조직의 임직원돌이 마케팅 개념에 대한 정확한 이해률 할 경우 판매중심 또는 사후적 고객만족에 국한된 편협한 사고에서 벗이나 사전적 기획, 실행, 통제의 체계적, 전략적 개념으로 받아드리도록 할 수 있고 이릵게 합으로쌔 마케텅부문의 경쟁우위와 기업성과를 기대할 수 있다. 또한 뚜렷한 마케팅 목표:의 설정은 마케팅전략 수립시 체계적인 접근을 가능케 하고 시장 세분화, 차별화, 포지셔닣과 같은 전략의 실행과 성과에 대한 평가를 가능케 한다. 그리고, 최고경영충이 마케팅의 중요성에 대한 인식과 의지의 표명은 마케팅 전략의 성공여부롤 가름할 수 있다. 이리한 마케텅 전략의 성과는 결과적으로 기업의 마케팅역량에 긍정적인 영향을 미칠 것이다. 기존연구에서 기업전략은 자원에 기초한 경쟁에 있어서 조직성과의 결정요인으로 밝혀젰다 (Amit 와 Schoemaker 1993; Mahoney 와 Pandian 1993; Hunt 와 Morgan 1995; Mavondo 1995). 또한 기존 연구들은 시장에서의 성과를 높이기 위해서는 경쟁과의 경쟁 우위적인 위치를 점해야 하며 마케팅 차별화는 이률 위한 수단이 된다고 주장하였다 (Porter 1985; Cooper \& Kleinschmidt 1985; Christensen 외 1987). 위의 선행연구에 의하여 다음과 같은 가실이 도출되었다.

가설 4a: 제조기업의 마케턍 전량ㅇㄴㄴ 마케팅역량에 정의 유의한 영향을 미친다.

가설 $4 \mathrm{~b}$ : 서비스기업의 마케팅 전략은 마케팅역량에 정의 유의한 영향을 미친다.

\section{6 마케팅 인력과 마케팅역량}

마케팅 인력은 마케텅 실무 경협의 정도와 마케팅 마인드의 구비, 그리고 마케팅 교역과 훈련으로 조작적 정의 되었다. 먼저 실무경험이 풍부한 전문가와 같은 양질의 마케팅 인적자원의 확보는 인적자원의 효율적 할용에 따른 마케텅 업무의 질을 향상시키는 역할을 한다. 또한 마케팅 업무의 중요성을 인식하고 새로운 마케팅 기법을 실무에 적용하려는 마케팅 실무자의 의지는 마케텅 성과를 제고 시킬 것이다. 그리고 환경의 변화에 따른 새로운 마케팅 기법의 교육과 정기적인 교육을 퉁해 마케팅의 발전적이고 창조적인 사고와 창의력을 키우는 노력은 조직의 마케팅역량 제고에 실질적이고 긍정적인 영향을 미칠 
것이다. Dess와 Origer (1987)는 역동적이고 복합적인 시장에서 고(高)성과 기업들은 창의성을 자극하는 경영기술을 지원하는 구성원의 공감대 형성을 강조하였다고 발표하였고, Sinkula (1994)는 인적자원 실천은 학습효과를 제고 시킴으로써 행동의 변화률 초래하고 기업성과률 제고 시킨다고 주장하였다. 이와같은 선행결과률 토대로 다음과 같은 가설이 도출되었다.

가설 5a: 제조기업의 마케팅 인력은 마케텅역량에 정의 유의한 영향을 미친다.

가설 $5 \mathrm{~b}$ : 서비스기업의 마케팅 인력은 마케팅역량에 정의 유의한 영향을 미친다.

\section{7 마케팅역량과 고객만족}

위의 <그림 $1>$ 에서 잠재종속변수로 나타나 마케팅역량에 의해 영향을 받는 것으로. 나타난 고객만족은 두개의 변수로 구성되었는데 첫 번째 항목은 설문 웅답자들에게 설문올 받은 당해 연도의 해당 고객만족지수의 수치에 대해 물어보았다. 두번쩨 항목은 웅답자 소속 기업의 전년도 대비 고객만족지수의 증가정도에 대해 물어보았다. 본 연구에 포함된 대상기업들은 모두 대기업 그륩으로써 매년 자체적으로 고객만족조사를 시행하고 있다. 고객 만족은 마케팅 조직내부적 역량의 표출된 결과라고 볼 수 있는데 마케팅역량이 높을수록 즉 제품과 유통 판촉과 가격에 있어서 경쟁력이 클수록 고객은 만족할 것이며 이는 기업의 고객만족지수에 실질적으로 반영될 것이다. 결과적으로 다음과 같은 가설이 도출될 수 있다.

가설 6a: 제조기업의 마케팅역량은 고객만족에 정의 유의한 영향을 미친다.

가설 6b: 서비스기업의 마케팅역량은 고객만족에 정의 유의한 영향을 미친다.

\section{8 설문항목 및 표본설계}

마케팅성과의 다섯 개 요인을 위주로 고안된 조사설문지는 7점 리커트 척도의 질문항목들이 사용되었다. 고객지향성 (3개), 마케팅 조직 (3개), 정보시스템 (3개), 마케팅 전략 (3개), 마케팅 인력 (3개)의 5개 요인, 충 15개 항목으로 구성되었다. 이와 함께 마케팅 믹스와 관련된 변수들로는 제품(6개), 유통(5개), 판촉(3개), 가격(4개) 부문과 관련하여 총 18 개 문항이 포함되었다. 별도로 기업관련 15 개 항목과 개인관련 4 개 항목이 포합되었다. 제조기업과 서비스기업간의 사업영역의 상이성에 따라 현장에서 수행되는 활동내용의 차이를 고려하여 제조기업과 서비스 기업은 설문지를 차별화하였다. 설문지 내용상의 주요한 차이는 마케텅 수행과 관련된 어휘의 선별적 사용에 두었는데 예를 들어 제조기업 설문지의 “제품”은 서비스기업 설문지에서 “서비스"로 대체하여 사용하였다.

전자, 기계, 화학, 금용, 서비스(일반) 등 다섯 개의 산업에 걸쳐 조사에 포함된 기업은 충 19 개이다. 제조업에는 전자, 기계, 화학 산업내의 10 개 기업이 포함되었으며 총 689 개의 설문이 회수되었고, 서비스업에는 금융, 서비스산업내의 9 개 기업이 조사대상으로 포함되었고 총 499 개의 설문이 회수되었다. 각 산업에서의 기업 선정은 전자, 기계, 화학, 금욯, 서비스를 모두 사업영역으로 하고 있는 한국의 대표적 재벌기업 중의 하나로 자체적인 고객만족 정보시스템을 구축하여 매년 측정하고 있으며 각 산업분야에서 대표적인 우량 기업들을 포합하고 있다. 산업별 표본 기업의 수와 표본크기는 <표 3>과 같다. 
<표 3> 산업별 표본수 및 사업분야

\begin{tabular}{|c|c|c|c|c|c|c|}
\hline & \multicolumn{3}{|c|}{ 제조 기업 } & \multicolumn{2}{|c|}{ 서비스 기업 } & 합계 \\
\hline 산업분류 & 전자 & 기례 & 화학 & 금응 & 서비스(일반) & \\
\hline 기업 수 & 4 & 3 & 3 & 4 & 5 & 19 \\
\hline 사업부 수 & 25 & 13 & 12 & 15 & 18 & 83 \\
\hline 표본수 & 383 & 210 & 96 & 215 & 284 & $1, \overline{188}$ \\
\hline 사업분야 & $\begin{array}{l}\text { 전자 } \\
\text { LCD/LFT } \\
\text { 전자부품 } \\
\text { 산업유리 }\end{array}$ & $\begin{array}{l}\text { 중공업 } \\
\text { 시계 } \\
\text { 항공 }\end{array}$ & $\begin{array}{l}\text { 종합화학 } \\
\text { 석유화학 } \\
\text { 정밀화학 }\end{array}$ & $\begin{array}{l}\text { 생명보헙 } \\
\text { 신용카드 } \\
\text { 종권 } \\
\text { 산업보혐 }\end{array}$ & $\begin{array}{l}\text { 리조트,호텔 } \\
\text { 보안시스템 } \\
\text { 유똫 } \\
\text { 의류 }\end{array}$ & \\
\hline
\end{tabular}

표본설계에서는 관련 부서간의 관계에서 발생하는 시너지 효과의 중요성을 고려하여서 전략기힉, 생산, 제품개발, 영업, 촉진, PR, 광고, 고객 서비스, 구매 후 서비스와 같은 마케팅 지원부서 돌도 표본에 포합시켰다. 본 연구예 사용된 기본적인 표본 설계 방법은 군집표본 추출법이었다. 단 전자산업의 경우, 기업 내 대규모 사업부가 서로 다른 성격의 사업을 운영하고 있었으므로 층화 표본추출울 사용하였다.

마케팅성과에 대해 상이한 직급에 따라 서로 다른 견해를 가지고 있을 수 있다는 판단 하에 응답자들을 직급에 따라 네 개의 그룸으로 나누었다. 네 개의 그룹은 각각 임원 $(5 \%)$, 차,부장 $(20 \%)$, 과장 $(30 \%)$, 대리 $(45 \%)$ 로 나누었다. 또한 웅답자의 기업의 마케팅 활동에 대한 친숙도를 고려해서 2 년 이상의 근무를 한 사람만이 조사대상에 포함되었다. 설문지는 전문조사 기관인 한국 갤럽에 의뢰하여 회수되었으며 응답률은 $69 \%$ 였다. 사용 불가능한 설문지 50 부를 제외한 최종분석에 사용된 설문지는 제조기업의 658 부 그리고 서비스기업의 480 부, 총 1,138 부였다.

\section{4. 실중적 검중결과}

\section{1 마케팅성과 요인의 검증}

개념타당성에 대한 정확한 분석을 위해 확인요인분석을 시행하였다. 분석을 위한 통계프로그램으로는 AMOS (v.4.0)률 사용하였다. 추정치는 최대 우도법(Maximum Likelihood Method)을 사용하였으며 표준화와 표준화되지 않은 수치를 보여주고 있다. 재조기업에 대한 요인분석결과는 <표4>에, 서비스기업에 대한 요인분석결과는 <표 $>$ 에 나타나 있다.

<표 4> 제조기업의 마캐탕 성과 영향요인에 대한 확인요인분석

\begin{tabular}{|c|c|c|c|c|c|}
\hline \multirow{2}{*}{ 요인명 } & \multirow{2}{*}{ 경로 } & \multicolumn{2}{|c|}{ 추정치 } & \multirow{2}{*}{ t-value } & \multirow{2}{*}{ Alpha } \\
\hline & & 표준화 & 비표준화 & & \\
\hline \multirow[t]{2}{*}{ 마켸팅 인력 } & $\rightarrow$ 마케팅 마인드 구비 & .819 & 1.000 & & \multirow[t]{2}{*}{.7424} \\
\hline & $\rightarrow$ 마케텅 경험 정도 & .708 & .952 & 14.448 & \\
\hline
\end{tabular}




\begin{tabular}{|c|c|c|c|c|c|}
\hline & $\rightarrow$ CS 결과 인사 반영도 & .580 & .700 & 12.943 & \\
\hline \multirow{2}{*}{ 마케팅 조직 } & $\rightarrow$ 마켸팅 조직의 조직력 & .783 & 1.000 & & \multirow{2}{*}{.7370} \\
\hline & $\rightarrow$ 마케팅부서의 위상 & .747 & 1.013 & 18.466 & \\
\hline \multirow{3}{*}{ 마케팅 전략 } & $\rightarrow$ 전략의 체계화 & .677 & 1.000 & & \multirow{3}{*}{.7612} \\
\hline & $\rightarrow$ 최고경영충의 의지 & .733 & 1.013 & 18.767 & \\
\hline & $\rightarrow$ 마캐텅 중요섬 인식 & .756 & 1.131 & 19.037 & \\
\hline \multicolumn{2}{|r|}{ 요인간 관계 } & 상관 & 공분산 & t-value & \\
\hline \multicolumn{2}{|c|}{ 마케팅 인력 $<-->$ 마케탕 조직 } & .505 & .637 & 9.430 & \\
\hline \multicolumn{2}{|c|}{ 마케팅 전략 $<-\rightarrow>$ 마케팅 조직 } & .720 & .734 & 13.075 & \\
\hline \multicolumn{2}{|c|}{ 마케팅 전략 <- -> 고객지향/인력 } & .376 & .419 & 7.356 & \\
\hline
\end{tabular}

Chi-square $=67.24(\mathrm{df}=17) \mathrm{p}=.000$

RMSR $=.052, \mathrm{GFI}=.985, \mathrm{NFI}=.997, \mathrm{RFI}=.993, \mathrm{CFI}=.998$

<표 5> 서비스기업의 마케텅 성과 영향요인에 대한 화인요인분석

\begin{tabular}{|c|c|c|c|c|c|}
\hline \multirow{2}{*}{ 요인명 } & \multirow{2}{*}{ 경로 } & \multicolumn{2}{|c|}{ 추정치 } & \multirow{2}{*}{ t-value } & \multirow{2}{*}{ Alpha } \\
\hline & & 표준화 & 비표준화 & & \\
\hline \multirow{3}{*}{ 마케팅 인력 } & $\rightarrow$ 마케팅경험의 정도 & .819 & 1.000 & & \multirow{3}{*}{.8178} \\
\hline & $\rightarrow$ 마케팅 마인드 구비 & .809 & 1.134 & 13.279 & \\
\hline & $\rightarrow$ 마케팅 교육과 훈련 & .714 & .890 & 11.909 & \\
\hline \multirow{2}{*}{ 마케팅 정보 } & $\rightarrow$ 정보시스템 활용정도 & .782 & 1.000 & & \multirow{2}{*}{.7814} \\
\hline & $\rightarrow$ 타부서와의 정보공유 & .821 & 1.108 & 11.366 & \\
\hline \multirow{2}{*}{ 고객지향성 } & $\rightarrow \mathrm{CS}$ 결과의 정책반영도 & .834 & 1.000 & & \multirow{2}{*}{.7387} \\
\hline & $\rightarrow \mathrm{CS}$ 업무의 중요도 & .706 & .821 & 8.406 & \\
\hline \multirow{2}{*}{ 마케팅 전략 } & $\rightarrow$ 최고경영층의 의지 & .875 & 1.000 & & \multirow{2}{*}{.8165} \\
\hline & $\rightarrow$ 마캐텅 중요성의 인식 & .821 & .929 & 11.818 & \\
\hline \multicolumn{2}{|r|}{ 요인간 관계 } & 상관 & 공분산 & t-value & \\
\hline \multicolumn{2}{|c|}{ 마케팅 인력 く- >> 마케텅 정보 } & .525 & .643 & 6.352 & \\
\hline \multicolumn{2}{|c|}{ 마케팅 정보 <- -> 고객지향성 } & .478 & .642 & 5.704 & \\
\hline \multicolumn{2}{|c|}{ 마케팅 전략 〈- > 고객 지향성 } & .390 & .548 & 5.040 & \\
\hline \multicolumn{2}{|c|}{ 마케팅 인력 $<-->$ 고객지향성 } & .614. & .894 & 6.937 & \\
\hline \multicolumn{2}{|c|}{ 마켸탕 전략 $-\rightarrow>$ 마캐팅 정보 } & .580 & .686 & 7.651 & \\
\hline \multicolumn{2}{|c|}{ 마케탕 전략 <- >> 마케팅 인력 } & .497 & .638 & 6.452 & \\
\hline
\end{tabular}

Chi-square $=36.65(\mathrm{df}=21), \mathrm{p}=.018$

RMSR $=.043, \mathrm{GFI}=.990, \mathrm{NFI}=.996, \mathrm{RFI}=.991, \mathrm{CFI}=.998$ 
제조기업에 대한 확인요인분석결과 7번의 반복(iteration)후에 RMSR가 .052이고 적합도 지표둘 (GFI=.985, NFI=.997, RFI=.993, $\mathrm{CFI}=998$ ) 이 모두 .99를 상회하는 모델을 구축하였다 (표 4 참조). 일반적으로 구조방정식에 쓰이는 지수로는 GFI, AGFI, NFI 둥이 있으며 이들은 0.90 이상일 경우 적합하며, RMSR은 0.5 이하일 경우 적합하다. 제조기업에서는 적합도 지표들온 큰 변함이 없이 노페 나왔다. 다음으로 마켸팅 조직요인에서는 "타 부서와의 협동” 변수가 가장 낮온 다중상관제곱결과를 보임으로써 이률 제거하고 나서의 Chi-square는 현재의 67.24로 낮아졌기 때문에 모델의 적합도가 개선되었다. 그러나 마케팅전랴 제거된 변수가 없었다. 다중상관 제곱 (squared multiple correlations) 은 각 변수가 요인울 설명하는 설명력을 나타내주며, 마케탕 인력 요인에서는 "마케팅 마인드구비" 변수가 가장 높게 나왔으며, 마케팅 조직 요인에서는 “마케팅 조직의 조직력”미, 마케탕 전략에서는 "마케팅 중요섬 인식"이 가장 는은 것으로 나타났다. 전반적으로 요인을 구성하는 변수듫의 높은 $\mathrm{t}$-값과 크론바하 알파도 수용가능 수준 $(.7$ 이상 $)$ 인 것으로 판명됩에 마라 개념타당성이 높은 것으로 나타났다.

서비스 기업들을 대상으로 한 확인요인분석결과 RMSR가 .043이고 GFI=.990, NFI=.996, $\mathrm{RFI}=.991, \mathrm{CFI}=.998$ 로 매우 높은 모델의 적합도를 보여주었다 (표 5 참조). 다중상관 졔곱 (squared multiple correlations) 에 있어서 마케팅인력요인에서는 “마케팅 교육과 훈련"미년수가 가장 높개 나왔으며(.671), 마케팅 정보 요인에서는 “타부서와의 정보공유” 변수가 가장 높게 (.695), 고객지향성요인에서는 “CS 결과의 정책반영도" 변수가 가장 높게(.695), 마케팅 전략에서는 “최고경영충의 의지”가미 가장 높게 (.765) 나타났다. 전반적으로 확인요인분석의 결과 요인을 구성하는 변수돌의 높은 $\mathrm{t}$-값과 수용할만한 크론바하 알파 (.7이상) 에 비추어 불 때 개념타당성이 적합한 것으로 결론 내릴 수 있다.

위의 두개의 분석을 중합적으로 비교해 보면, 제조업과 서비스업에서는 마캐팅성과의 5 개 요인이 그 개념적 인식을 달리한다고 불 수 있다. 즉, 제조기업의 종사자들은 마케팅 성과에의 영향요인을 “마케팅 인력”, “마케팅 조직", “마케팅 전략”의 세 요인으로 구성뎌어 있다고 인식하며, 서비스기업 종사자돌온 “마케팅 인력", “마케텅 정보”, “고객지향성”, "마케팅 전략"으로 구성된다고 인식하였다. 이 결과에서 유의할 점은 서비스기덥은 제조기업보다 고객지향성과 마케팅 정보률 중시하였고 제조기업은 서비스기업보다 마케팅 조직울 중시하였다는 점이다.

\section{2 마케팅역량 요인}

본 연구의 연구목적에서 기술된 바와 같이 마케팅성과의 척도개발과 관련한 예측타당성을 검중하기 위한 목적으로 구조방정식모형을 이용하여 마케텅성과의 5 개의 선행 요인줄이 마케텅성과에 영향을 미치는 지와 또한 그 요인들이 마케팅역량과 고객만족에 어떠한 영향을 주는지률 규명하기로 하였다. 중속변수로는 마케팅역량과 고객만족이라는 2개 개념을 사용하여 마케팅성과률 측정하였다. 먼저 마케팅 성과에 반영할 목적으로 마케텅믹스가 제조와 서비스 기업 내에서 얼마나 성공적으로 실행되는가를 보기로 하였다. 즉 설문에 포함된 마케텅 믹스요인에 관한 18 개 문항을 제품력, 유통력, 판촉력, 가격력으로 구분하여 사용하였으며 이를 충칭하여 마케팅역량으로 명칭 하였다. 이돌 변수에 견한 요인분석 결과는 다음 표와 같다. 
<표 6> 제조기업과 서비스기업간의 마케팅역량의 선행 요인들의 요인분석 결과 비교

\begin{tabular}{|c|c|c|c|c|c|c|c|}
\hline \multicolumn{4}{|c|}{ 제조 기업 } & \multicolumn{4}{|c|}{ 서비스 기업 } \\
\hline 요인 & $\begin{array}{l}\text { 적재 } \\
\text { 값 }\end{array}$ & $\begin{array}{l}\text { Eigen } \\
\text { value }\end{array}$ & $\begin{array}{l}\text { 알패 } \\
\text { 계수 }\end{array}$ & 요인 & $\begin{array}{l}\text { 적제 } \\
\text { 값 }\end{array}$ & $\begin{array}{l}\text { Eigen } \\
\text { value }\end{array}$ & $\begin{array}{l}\text { 알 좌 } \\
\text { 계 수 }\end{array}$ \\
\hline 재품력 & & & & 제품력 & & & \\
\hline 상품개발시 타부서 참여 & .654 & & & 상품개발시 타부서 참여 & .728 & & \\
\hline 상품개발의 시장욕구 반영 & .760 & & & 상품개발의 시장욕구 반영 & .744 & & \\
\hline 시장수요예촉의 정확성 & .744 & 6000 & 97 & 시장수요여측의 정학성 & .749 & 7.417 & .858 \\
\hline 포트폴리오 전략의 활용 & .755 & 0.400 & $.8 \pi$ & 포트폴리오 전략의 활용 & .722 & & \\
\hline 주력상품의 품질 인정 & .731 & & & 주력상품의 품질 인정 & .692 & & \\
\hline 주력상품의 디자인 인정 & .780 & & & & & & \\
\hline 유통력 & & & & 유통력 & & & \\
\hline 유통정보 기술의 활용 & .679 & & & 판매망에 대한 퉁제력 & .850 & & \\
\hline 판매원에 대한 교욱투자 & .762 & & & 판매원에 대한 통제력 & .814 & & \\
\hline 판매망에 대한 퉁제력 & .767 & 1.772 & .768 & 판매원에 대한 교육투자 & \begin{tabular}{|l|}
.689 \\
\end{tabular} & 2.140 & -823 \\
\hline 판매원에 대한 보상 & .745 & & & 판매원에 대한 보상 & .676 & & \\
\hline 판촉력 & & & & 판촉력 & & & \\
\hline 판촉비용의 적정성 & .765 & & & 판촉비용의 적정성 & .744 & & \\
\hline 팬촉효과의 측정 & .830 & 1.333 & 873 & 판족효과의 측정 & .830 & 1.606 & .865 \\
\hline 판촉효과의 전략반영 & .823 & & & 판촉효과의 전락반영 & .747 & & \\
\hline 가격력 & & & & 가격력 & & & \\
\hline 가격책정의 시장 선도력 & .697 & & & 가격책정의 시장 선도력 & .796 & & \\
\hline 가격정책의 환경 대응력 & .708 & 1770 & 7ר? & 가격정책의 환경 대웅력 & .785 & 1200 & 092 \\
\hline 상품의 가격인하 내구력 & .729 & 1.219 & .122 & 상품의 가격인하 내구력 & .753 & 1.308 & .803 \\
\hline 매출의 가격정책 의존성 & .640 & & & 매출의 가격정책 의존성 & .782 & & \\
\hline
\end{tabular}

요인분석의 결과를 보면 게조기업과 서비스기업 모두 유사한 요인으로 구성되어 있음을 알 수 있다. 제품력과 유봉력을 제외한 판촉력과 가격력의 요인들은 같은 항목들로 구성되었다. 제조기업에서는 제품력, 유통력, 푠촉력, 가격력 모두.72 이상의 크론바하 알파계수를 나타쌨다. 서비스기업에서는 요인들의 알파값이 좀더 높게 나아 모두 .82이상으로 나타났다. 요인구성 항목들을 보면 제조기업에서는 유톻력 요인에서 1 개 항목 (판매원에 대한 통제력)이 제거되었다. 서비스기업에서는 유통력 요인에서 유통정보기술의 활용이 제거되었다. 제품력 요인에서 “주력상품의 디자인인정"은 제조기업에만 국한되어 설문항목에 포함되었으므로 서비스기업에서는 요인에 포함되지 않았다.

\section{3 수정 (revised) 마케팅 성과모델}

앞서의 확인요인분석 결과에 따른 제조기업에 유의한 마케팅 성과요인돌과 마케팅역럏, 고객만족 간의 관계를 보여주는 수정 마케팅성과모델율 검중하기 위한 구조방정식 모형난 
아래 그림과 같다. <표 4>에서의 확인요인분석결과률 반영하여 $\mathrm{H} 2 \mathrm{a}, \mathrm{H} 4 \mathrm{a}, \mathrm{H} 5 \mathrm{a}$ 만이 가설검중대상예 포함되었다.

\section{〈그립 2〉 제조기업의 마케팅 성과모델}

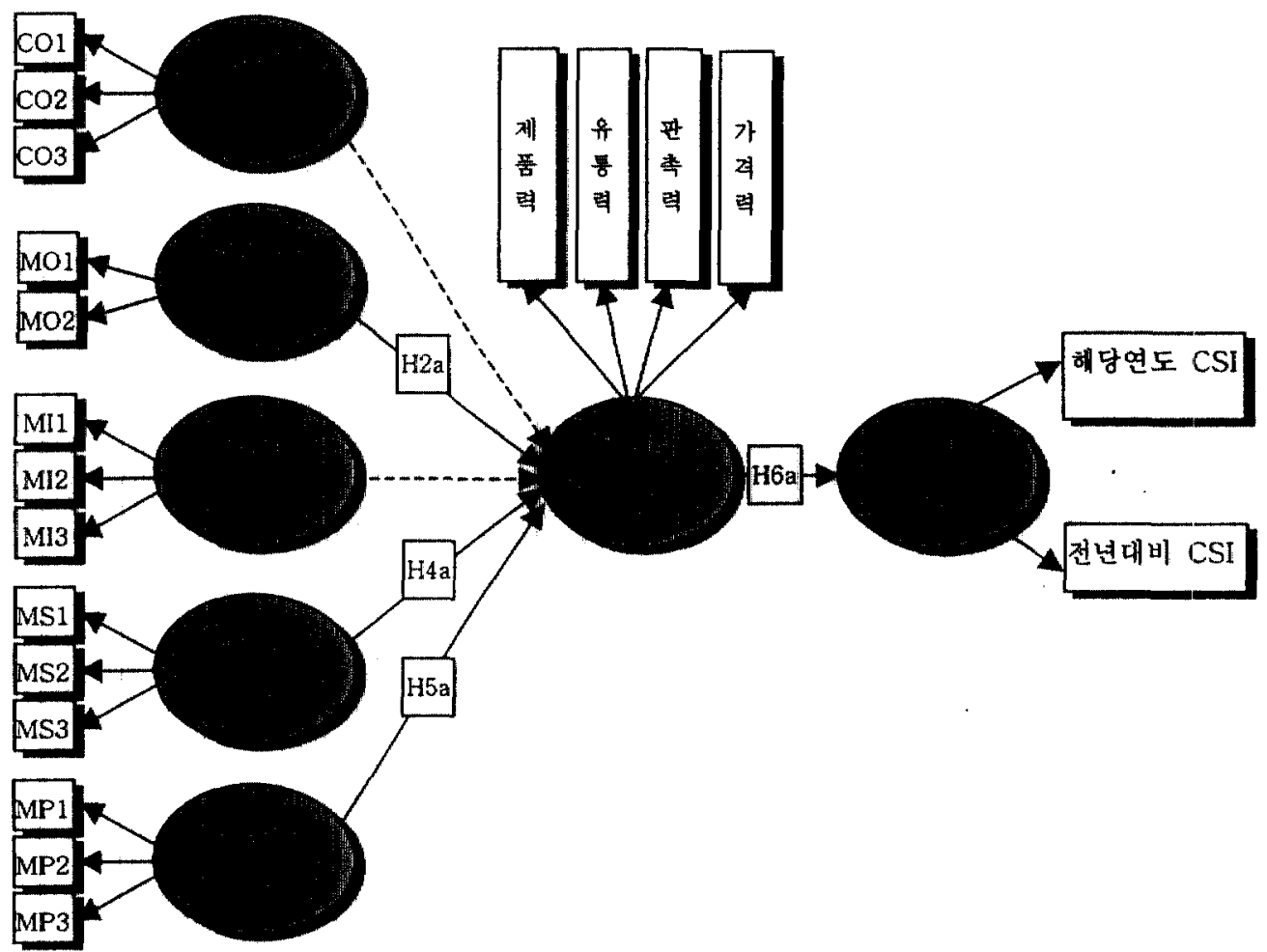

위의 수정마케팅성과모델에 기반 하여 제조기업에 대한 가설 $\mathrm{H} 2 \mathrm{a}, \mathrm{H} 4 \mathrm{a}, \mathrm{H} 5 \mathrm{a}$ 의 검중을 위한 구조방정식모형의 적합성 검증결과는 <표 $7>$ 과 같다.

<표 7> 제조기업에 대한 구조방정식모형의 적합성 결과

\begin{tabular}{|c|c|c|c|c|}
\hline \multirow{2}{*}{ 잠재변인 } & \multicolumn{2}{|c|}{ 추정치 } & \multirow{2}{*}{ 표준오차 } & \multirow{2}{*}{$t$ 㺖 } \\
\hline & 비표준화 & 표준화 & & \\
\hline 마케팅역량 $\leftarrow$ 마케팅 인력 & 3.052 & .637 & .295 & 10.347 \\
\hline 마케텅역량 $\leftarrow$ 마케팅 조직 & .648 & .203 & .130 & 5.002 \\
\hline 마케팅역량 $\leftarrow$ 마케팅 전략 & .327 & .100 & .124 & 2.635 \\
\hline 고객만족 $\leftarrow$ 마케팅역량 & .054 & 1.000 & .099 & 2.541 \\
\hline 마케팅의 경헙 정도 $\leftarrow$ 마케팅 인력 & 1.000 & .723 & & \\
\hline 마케텅 마인드 구비 $\leftarrow$ 마케팅 인력 & 1.253 & .781 & .084 & 14.976 \\
\hline CS결과 인사 반영도 $\leftarrow$ 마케팅 인력 & 640 & .365 & .076 & 8.428 \\
\hline 마케텅부서의 위상 $\leftarrow$ 마케팅 조직 & 1.000 & .999 & & \\
\hline
\end{tabular}




\begin{tabular}{|c|c|c|c|c|}
\hline 마케팅조직의 조직력 $\leftarrow$ 마케팅 조직 & .552 & .586 & .023 & 24.184 \\
\hline 마케팅 중요성인식 $\leftarrow$ 마케팅 전략 & 1.000 & .999 & & \\
\hline 최고경영충의 의지 $\leftarrow$ 마케팅 전락 & .549 & .593 & .033 & 24.184 \\
\hline 전략의 체계화 $\leftarrow$ 마케팅 전랴 & .486 & .492 & .026 & 18.549 \\
\hline 제품력 $\leftarrow$ 마케팅역량 & 1.000 & .673 & & \\
\hline 유통력 $\leftarrow$ 마케텅역량 & .496 & .490 & .047 & 10.604 \\
\hline 판촉력 $\leftarrow$ 마케팅역량 & .443 & .572 & .038 & 11.780 \\
\hline 가격력 $\leftarrow$ 마케팅역량 & .716 & .680 & .055 & 13.131 \\
\hline 고객만족지수 $\leftarrow$ 고객만족 & 1.000 & .020 & & \\
\hline 전년대비 만족향상 $\leftarrow$ 고객만족 & .396 & .060 & .035 & 7.514 \\
\hline
\end{tabular}

Chi-square $=105.71(\mathrm{df}=67) \mathrm{p}=.01$

$\mathrm{RMSR}=.060, \mathrm{GFI}=.967, \mathrm{NFI}=.991, \mathrm{RFI}=.986, \mathrm{CFI}=.993$

분석결과를 살펴보면, 먼저 모델의 적합도는 chi-square 값이 105.71 에 p 값이 .01, 그리고 RMSR 은 .060 로 적정수준(.05)보다 조금 낮았으나, 다른 접합도 지수인 GFI, NFI, $\mathrm{RFI}, \mathrm{CFI}$ 는 모두 .960 이상으로 만족할만한 수치를 나타내었다. 제조기업의 마케팅성과를 구성하는 3 개 요인들, 즉 마케팅 인력 $(\mathrm{t}=10.347)$, 마케팅 조직 $(\mathrm{t}=5.002)$, 그리고 마캐탕 전략 $(t=2.635)$ 은 모두 마케빙역량에 유의한 정의 영향을 미치는 것으로 나타났다. 또한 마캐팅역량도 2.541 로 나타나 고객만족에 와의한 영향을 주는 것으로 나타났다.

다음으로 서비스기업에 유의한 마케팅 성과요인둘과 마케팅역량, 고객만족 간의 관계를 보여주는 수정 마케팅성과모델에 관한 구조방정식 모형은 아래 그림과 같다. <표 5>에서의 확인요인분석결과 가설 $\mathrm{H} 1 \mathrm{~b}, \mathrm{H} 3 \mathrm{~b}, \mathrm{H} 4 \mathrm{~b}, \mathrm{H} 5 \mathrm{~b}$ 만이 분석에 포합되었다.

〈그립 3> 서비스기업의 마케팅성과모델

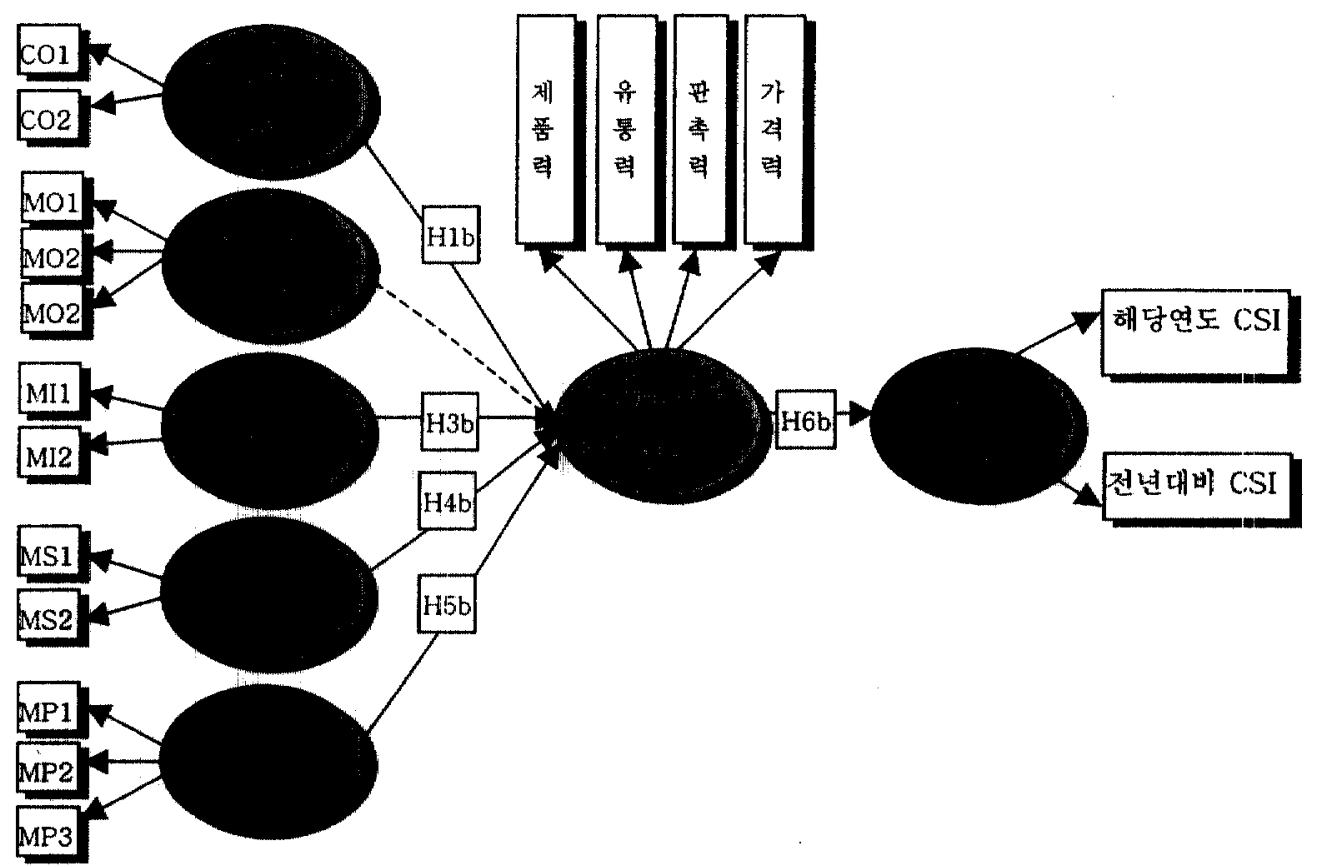


서비스기업에 대한 가설 $\mathrm{Hlb}, \mathrm{H} 3 \mathrm{~b}$. H4b, H5b의 검증을 위한 구조방정식모형의 적합성 분석결과는 다음과 같다.

<표 8> 서비스기업에 대한 구조방정식모형의 분석결과

\begin{tabular}{|c|c|c|c|c|}
\hline \multirow{2}{*}{ 잠재변인 } & \multicolumn{2}{|c|}{ 추정치 } & \multirow{2}{*}{ 표준오차 } & \multirow{2}{*}{ t 값 } \\
\hline & 비표준화 & 표준화 & & \\
\hline 마케팅역량 $\leftarrow$ 마케텅 인력 & 1.826 & .361 & .349 & 5.228 \\
\hline 마케팅역량 $\leftarrow$ 고객지향성 & .935 & .245 & .198 & 4.718 \\
\hline 마케팅역량 $\leftarrow$ 마케팅 전략 & 1.028 & .195 & .310 & 3.318 \\
\hline 마켸팅역량 $\leftarrow$ 마케팅 정보 & 1.696 & .395 & .218 & 7.779 \\
\hline 고객만족 $\leftarrow$ 마케팅역량 & 1.319 & 1.000 & .383 & 3.44 .1 \\
\hline 마케팅 마인드 구비 $\leftarrow$ 마케팅인력 & 1.000 & .813 & & \\
\hline 마켸팅의 경험 정도 $\lessdot$ 마케팅인력 & 1.153 & .816 & .084 & 13.790 \\
\hline 마케팅 교욕과 훈련 $\leftarrow$ 마케팅인력 & .907 & .724 & .074 & 12.271 \\
\hline CS결과의 정책반영도 $\leftarrow$ 고객지향성 & 1.000 & .999 & & \\
\hline CS업무의 중요도 $\leftarrow$ 고객지향성 & .570 & .591 & .046 & 12.313 \\
\hline 정보시스템의 할용 $\leftarrow$ 마케팅 정보 & 1.000 & .999 & & \\
\hline 타부서와의 정보공유 $\leftarrow$ 마케팅 정보 & .680 & .644 & .040 & 16.859 \\
\hline 최고경영훙의 의지 $\leftarrow$ 마케팅 전략 & 1.000 & .869 & & \\
\hline 마케팅 중요성의 인식 $\leftarrow$ 마케텀 전략 & .941 & .794 & .077 & $12.2, \overline{24}$ \\
\hline 제품력 $\leftarrow$ 마케팅역량 & 1.000 & .783 & & \\
\hline 유통력 $\leftarrow$ 마케팅역량 & .400 & .543 & .045 & 8.972 \\
\hline 판촉력 $\leftarrow$ 마케딩역량 & .519 & .662 & .043 & 11.965 \\
\hline 가격력 $\leftarrow$ 마케팅역량 & .544 & .555 & .059 & 9.189 \\
\hline 고객만족지수 $\leftarrow$ 고객만족 & 1.000 & .216 & & \\
\hline 전년대비 만족향상 $\leftarrow$ 고객만족 & .231 & .121 & .019 & 1.984 \\
\hline
\end{tabular}

Chi-square $=92.45(\mathrm{df}=78) \mathrm{p}=.04$

$\mathrm{RMSR}=.052, \mathrm{GFI}=.971, \mathrm{NFI}=.982, \mathrm{RF}=.973, \mathrm{CFI}=.988$

서비스 기업에 관한 구조공분산모형의 분석결과 모델의 적합도는 chi-square 값이 92.45에 p값이 .04였으며 RMSR은 .052로 적정수준(.005)에 근접하였고, 다른 접합도 지수인 GFI, NFI, RFI, CFI는 모두 $\mathbf{9 7 0}$ 이상으로 만족할만한 적합성을 나타내었다. 분석내용율 보면, 마케텅인력(t=5.228), 고객지햫성(t=4.718), 마케텅전략 ( $t=3.318)$, 마케텅정보( $t=7.779)$ 는 모두 마캐텅역량에 유의한 정의 영향을 나타냈다. 또한 마케텅역량은 고객만족에 유의한 영향을 보여주었다 ( $t=3.441)$. 제조기업과 서비스기업의 구조공분산모형의 분석졀과 가설 $\mathrm{H} 1 \mathrm{~b}, \mathrm{H} 2 \mathrm{a}$, $\mathrm{H3a}, \mathrm{H4a}, \mathrm{H} 4 \mathrm{~b}, \mathrm{H} 5 \mathrm{a}, \mathrm{H} 5 \mathrm{~b}$ 들은 모두 채택되었다. 즉, 제조기업과 서비스기업의 최종마케팅성과모델은 <그림2>의 수정 마케팅성과모델을 수용할 수 있음을 중명한 것이다..

다음으로는 제조기업과 서비스기업간에 존재하는 잠재독립변수인 마케텅성과요인의 차이률 보기 위하여 각 요인의 평균치를 소속 산업별로 비교하였으며 같은 요인 내에서의 
산업간 차이률 보기 위하여 일원 ANOVA 분석을 실행하였다. 그 결과는 다음 표와 같다.

<표 9> 제조기업과 서비스기업의 요인별 평균치 및 일원 ANOVA 결과

\begin{tabular}{|c|c|c|c|c|c|c|}
\hline 산업 구분 & \multicolumn{4}{|c|}{ 잠제독립 요인 } & \multicolumn{2}{|c|}{ 잠재중속요인 } \\
\hline 재조기업 & $\begin{array}{l}\text { 마케텅 } \\
\text { 전랴 }\end{array}$ & $\begin{array}{l}\text { 마케텅 } \\
\text { 인력 }\end{array}$ & $\begin{array}{l}\text { 마케팅 } \\
\text { 조직 }\end{array}$ & & 마케팅역량 & 고객만족 \\
\hline 전자 & $4.82(1.09)$ & $4.42(1.16)$ & $4.11(1.09)$ & & $4.33(1.01)$ & $3.58(2.60)$ \\
\hline 기계 & $4.61(1.20)$ & $4.34(1.29)$ & $3.74(1.11)$ & & $3.95(.86)$ & $3.60(2.30)$ \\
\hline 화학 & $5.50(.98)$ & $4.41(1.04)$ & $4.37(1.13)$ & & $4.43(.99)$ & $2.15(2.39)$ \\
\hline 제조 평균 & $4.85(1.14)$ & $4.39(1.18)$ & $4.03(1.12)$ & & $4.21(.97)$ & $3.11(2.48)$ \\
\hline SS (df) & $897.37(680)$ & $554.65(392)$ & $863.37(680)$ & & $375.69(392)$ & $247.18(392)$ \\
\hline$F$ (sig) & $19.39(.000)$ & $.19(.823)$ & $12.00(.000)$ & & $7.97(.000)$ & $3.23(.041)$ \\
\hline 서비스기업 & $\begin{array}{l}\text { 마케팅 } \\
\text { 전략 }\end{array}$ & $\begin{array}{l}\text { 마케텅 } \\
\text { 인력 }\end{array}$ & 고객지향성 & $\begin{array}{l}\text { 마케팅 } \\
\text { 정보 }\end{array}$ & 마케팅역량 & 고객만족 \\
\hline 금욥 & $4.99(1.09)$ & $5.04(1.29)$ & $5.19(1.23)$ & $4.15(1.12)$ & $4.61(1.00)$ & $2.72(1.95)$ \\
\hline 서비스(일반) & $5.26(1.35)$ & $4.94(1.13)$ & $4.24(1.15)$ & $4.20(1.09)$ & $4.66(.78)$ & $4.18(1.74)$ \\
\hline 서배스 평균 & $5.07(1.18)$ & $5.01(1.24)$ & $4.91(1.28)$ & $4.16(1.11)$ & $4.63(.94)$ & $3.45(1.98)$ \\
\hline SS (df) & $313.54(225)$ & $351.48(225)$ & $371.79(225)$ & $278.05(225)$ & $201.35(225)$ & $882.23(225)$ \\
\hline F (sig) & $2.635(.106)$ & $.319(.573)$ & $28.97(.000)$ & $.119(.731)$ & $.099(.754)$ & $23.29(.000)$ \\
\hline $\begin{array}{c}\text { 평균의 차이 } \\
\text { T(prob) }\end{array}$ & $\begin{array}{l}\text { 마케팅 } \\
\text { 전략 }\end{array}$ & $\begin{array}{l}\text { 마케팅 } \\
\text { 인력 }\end{array}$ & & & 마케팅역량 & 고객만족 \\
\hline & $2.34(.083)$ & $6.69(.000)$ & & & $5.09(.010)$ & $4.37(.031)$ \\
\hline
\end{tabular}

\footnotetext{
*괄호안 숫자는 표준편차를 나타냄
}

위의 결과를 보면 제조기업과 서비스기업은 어느 정도의 공톻점과 상이점을 보여준다. 제조기업과 서비스 기업 공통적으로 마케팅전략과 마케팅 인력이 각각 1 위와 2 위 점수를 차지하였다. 제조기업은 마케팅전략을 선두로 하여, 마케팅 인력, 마케팅 조직이 그 뒤를 따랐다. 서비스기업에서는 마케텅전략에 이어 마케팅인력, 고객지향성, 마케텅정보가 뒤롤 따랐다.

제조기업과 서비스기업의 평균차이를 $\mathrm{t}$-검증한 결과 전반적으로, 서비스기업들이 제조기업들보다 통계적 ( $\mathrm{p}<.05$ 수준)으로 더 높은 점수들을 보였다. 서비스 기업들은 3 개 요인의 평균치가 제조 기업돌의 평균 성과치를 상회하였다. 구체적으로, 마켸팅 전략을 제외한 마케팅 인력 (서비스 5.01 대 제조 4.39), 마케팅역량(서비스 4.63 대 제조 4.21)과 고객만족( 서비스 3.45 대 재조 3.11)에 있어서 서비스기업이 제조기업보다 더 우세한 것으로 나타났다. 요인별 산업간의 차이를 보면 마캐팅 전략에 있어서는 화학제조기업 (5.50)이 가장 높은 점수를 나타냈고, 기계제조기업 (4.61)이 가장 낮은 점수를 보여주었다. 고객만족은 서비스 (일반) 기업이 4.18로 가장 높고, 화확이 2.15 로 가장 낮았다.

산업간의 잠재독립요인의 차이를 보기위해 실행한 일원분산분석 결과를 보면 대체적으로 
제조기업이 서비스기업보다 산업간의 차이가 더 큰 것으로 나타넜다. 예를 들면 제조기업에서는 마케팅 전략 $(\mathrm{F}=19.39 \mathrm{p}=.000)$ 과 마케팅 조직 $(\mathrm{F}=12.00, \mathrm{p}=.000)$, 그리고 마케팅역량 $(\mathrm{F}=7.97, \mathrm{p}=.000)$, 고객만족 $(\mathrm{F}=3.23, \mathrm{p}=.041)$ 에 있어서 유의한 평균의 차이률 보였다. 그러나 서비스 기업은 단지 고객지향성 $(\mathrm{F}=28.97, \mathrm{p}=.000)$ 과 고객만족 $(\mathrm{F}=23.23$, $\mathrm{p}=.000$ )에서만 유의한 차이를 보였다. 전체산업을 보았을 때, 마케팅역량은 제조산업 $(\mathrm{p}=.000)$ 이 서비스산업(.754) 보다 더 많은 평균치의 분산이 존재하였고, 고객만족을 보면 서비스산업 ( $\mathrm{p}=.000)$ 이 제조산업보다 (p.041) 더 많온 평균의 분산이 발견되었다. 이와 같은 발견은 제조기업이 속한 산업관련톡성의 차이가 서비스 산업의 특성보다 더 균열적으로 나타낪다고 해석할 수 있다.

\section{5. 결론 및 시사점}

\section{1 연구결과와 시사점}

본 연구는 Kotler (1988)의 마케팅성과 모델에 근거하여 새로운 요인을 추가한 수정 마케팅성과모델을 개발하고, 이 모델을 이용하여 한국의 체조산업과 서비스산업분야에서 높은 매출액비중을 차지하는 기업둘의 마케팅역량과 고객만족 수준을 측정하여 보았다. 요인분석 결과, 제조업과 서비스업은 마케팅성과 모델의 구성요인에 있어서 차이점을 나타냈다. 제조기업은 마케팅인력, 마케팅 조직, 마케팅 전략의 세 요인이 유의한 요인으로 나타넜으나, 서비스 기업에서는 마케팅 인력, 마케팅 정보, 고객지향성, 마캐팅 전략의 4요인이 유의하게 나타넜다. 이는 제조기업의 마케팅성과개념에 있어서 마케텅정보가 서비스기업보다 상대적으로 낮은 중요성을 차지한다는 것을 의미한다. 이 결과는 제조 기업들의 정보시스템 개발 또는 활용정도가 낮기 때문에 포함되지 않았다고 해석할 수 있다. 즉, 제조기업에서는 고객지향적 마케팅시스템의 필요성이 마케팅 성과에 미치는 영향력이 서비스 기업보다 낮다고 결론지울 수 있다.

서비스기업에서는 마케팅 조직이 마케팅성과에 미치는 영향이 제조기업보다 상대적으로 그 중요성이 낮다고 나타났다. 이 결과는 서비스의 특성인 무형성, 생산과 소비의 비분리성, 이질성, 그리고 소멸성에 기인한 유동성의 중요성에 비추어보아 조직의 유동성이 강조되는 만큼, 부서조직의 조직력 또는 위상과 같은 조직의 유형성이 상대적으로 덜 중요하다는 것을 의미한다고 볼 수 있다. 이와 같은 결과는 바뀌어 생각해서 재조기업이 서비스기업보다 마케팅 조직을 마케팅성과개념으로서 더 중요시 하고, 서비스기업에서는 재조기업보다 마케팅 정보률 더 중요시 한다는 논리와 상통한다.

구조방정식의 결과는 대체적으로 제조기업과 서비스기업에 있어서 공통젹으로 마케팅성과요인과 마케팅역량, 그리고 고객만족 간의 유의한 인과관계를 검중혜 주었다. 또 다론 중요한 발견은 서비스기업이 마케팅성과요인과 결과 변수인 마케팅역량과 고객만족에 있어서 상대적으로 제조기업들보다 높은 점수률 보였다는 것이다. 이 사실은 제조업의 톡성상 고객보다는 제조와 효율에 대해 더욱 중요성이 강조둴 수 있다는 보다 현실적인 관점에서 설명될 수 있다. 즉, 서비스기업은 고객과 더욱 밀접하게 관련되어야 하므로 더욱 고객지향적인 기술을 요구 받아 왔다는 점에서 설득력을 가질 수 있다. 


\section{2 추후연구의 필요성}

본 연구는 이종 산업 간의 산업적 특성을 고려하여 마케텅성과와 마케팅역량과 같온 객관적이고 검증 가능한 마케팅의 이론적, 전략적 모델에 근거하여 산업간의 비교를 시도하였다는 점에서 연구의 가치와 의미롤 찾아 볼 수 있올 것이다. 추후의 연구는 마케팅성과에 대한 기업환경의 영향력을 규명할 필요가 대두된다. 본 연구의 결과는 산업적 환경적 톡성의 역할을 고려하지 않았으므로 추후의 연구는 어떤 환경요인에 기인하여 예를 들면 화학산업의 제조기업과 기계산업의 재조기업의 마케팅 성과가 달라지는가에 대한 대답을 찾을 수 있을 수 있어야 할 것이다. 이는 산업의 특성, 즉 산업의 변화속도의 강약. 고객 니즈의 변화의 속도, 또는 제품의 기술변화에 대한 민감성 등과 같은 환경요인올 추가로 포함시킬 필요가 있다고 본다. 또 다른 연구방법으로 시장점유 또는 매출이나 이의 수준과 같은 좀더 객관적이고 결과 지향적인 성과 지표를 사용하여 마케팅성과를 측정할 누 있는 모델을 개발할 필요가 있다고 본다. 마지막으로 제품력, 유톻력, 판촉력, 가격력온 마케팅 조직의 기본적인 수행역량(capacity)으로 해석할 수도 있으므로 추후연구에서는 마케팅역량을 “마케팅 실천력" 과 같온 독립변수로 사용하여 고객만족에 대한 영향을 볼 수도 있을 것이다. 


\section{〈참고문헌>}

권영철 (1996), "시장지향성이 성과에 미치는 영향: 수출기업의 경우,므ㅁㅏㅐ케팅 뗜구, 한국마케텅학화, 제 11 권 제1호, pp.35-48.

김용준, 김진수 (1996), "서비스기업의 시장지향성, 고객만족도, 기업성과에 관한

모델설정과 실증연구,만국소비자하희 학술대희논문집.

신유근 (1994), 한국대기업의 경영특성: 5 대그룹의 주요 기업연구, 세경사

이용기, 유동근, 이학식 (1996), “시장지향성: 선행요인, 매개요인, 그리고 성과간의 구조적

관계,마에케팅연구, 한국마케팅학화, 제11권 제2호, pp. 161-181.

이유재 (1997), 서비스 마케텅, 학현사

전인수, 한재용 (1994), "시장지향성이 성과에 미치는 영향에 관한 연구,ㅁㅁ마케팅뎐구,

한국마케팅학회, 제9권 제1호, pp.75-91.

Amit, R., Schoemaker, P.J.H. (1993), "Strategic Assets and Organizational Rents,"

Strategic Management Journal, Vol 14, No.1, pp.33-46.

Appiah-Adu, K., Alan Fyall, and Satyendra. Singh (2001), "Journal of Services Marketing,

"Marketing Effectiveness and Business Performance in the Financial Services

Industry," Journal of Services Marketing, Vol.15, No.1, pp.18-34.

Christensen, C.H., Angela da Rocha and R.K. Gertner, (1987), "An Empirical

Investigation of the Factors Influencing Exporting Success of Brazilian Firnas,"

Journal of International Business Studies, (Fall), pp. 61-77.

Cooper, R.G. and Kleinschmidt, E.J. (1985), "The Impact of Export Strategy on Export

Sales Performance, " The Joumal of International Business Studies, Vol. 16, pp.3755.

Day, George S. (1994), The Capabilities of Market-Driven Organizations, Journal of Marketing, 58(October), 37-52.

Day, George S. and Wensley, R. (1988), "Assessing Advantage: A Framework for

Diagnosing Competitive Superiority," Journal of Marketing, vol. 52 (April), pp.1-20.

Desphande, Robit, John U. Farley, and Fredrick E. Webster, Jr. (1993), Corporate

Culture, Customer Orientation, and Innovativeness in Japanese Firms: A Quadrad Analysis, Journal of Marketing, 57 (January), 23-27.

Dess, G.G. and Origer, N.K. (1987), "Environment, Structure and Consensus in Strategy

Formulation: A Conceptual Integration," Academy of Management Review (April), Vol

12, pp.313-330.

Dunn, M., Norburn, D. and Burley, S. (1994), "The Impact of Organizational Values, Goals and Climate on Marketing Effectiveness," Journal of Business Research, Vol. 30, pp.131-141.

Ghosh, B., Schoch, H., Kwan, W., Kim, T. and Yau, O. (1993), "Australia and Singapore's

Top Performing Organizations: A Comparative Study of Their Marketing Effectiveness," Journal of International Marketing and Marketing Research, Vol. 18, No. 3, pp.115-139.

Gowen III, Charles R. and Tallon, William J. (1999), "Quality Management Practices in 
Manufacturing and Services Corporations: How Are They Different?" Mid-American Journal of Business, (Spring) Vol. 14, pp.33-41.

Greenley, Gordon E. (1995), Market Orientation and Company Performance: Empirical Evidence From UK Companies, British Journal of Management, Vol.6, 1-13, pp. 1-13. Hunt, Shelby D. and Robert M. Morgan (1995), The Comparative Advantage Theory of Competition, Journal of Marketing, Vol. 59 (April), 1-15.

Jahja, Henry and Kleiner, Brian H. (1997), "Competency-Based Pay in the Manufacturing and Service Sectors," Industrial Management, Vol 39, Issue 5, pp24-30.

Japan Management Association Consulting (1996). A Pathway to 21 Century Innovative Company (High Marketing Innovation)

Jaworski, Bernard J. and Ajay K. Kohli (1993), Market Orientation: Antecedent and Consequences, Journal of Marketing, 57 (July), 53-70.

Kin, Chung Woon (2000), "TQM implementation: Comparing Singaapore's Service and Manufacturing Leaders," Managing Service Quality, Vol.0, No. 5, pp.318-331.

Kohli, Ajay K. and Bernard J. Jaworski (1990), Market Orientation: The Construct, Research Propositions, and Managerial Implications, Journal of Marketing, 54 (April), $1-18$.

Kotler, Philip (1977), From Sales Obsession to Marketing Effectiveness, Harvard Business Review, (Non-Dec), pp.67-75.

Kotler, Philip (1988), Marketing Management: Analysis, Planning, and Control, Englewood Cliffs, NJ: Prentice-Hall, Inc.

Kotler, Philip (1994), Marketing Management: Analysis, Planning, Implementation, and' Control, 8th ed. Englewood Cliffs, New Jersey: Prentice Hall, Inc.

Kotler, Philip, William Gregor, and William Rogers (1984), The Age of Audit Comes of Age, in Strategic Marketing: Planning, Implementation and Control, eds. Bouton A. Weitz and Robin Wensley, Kent Publishing Company.

Kozicki, Sharon (1997), "The Productivity Gowth Slowdown: Diverging Trends in the Manufaturing and Servie Sectors," Economic Review (Federal Researve Bank of Kansas City), Vol.82, Issue 1, pp.31-47.

Lai, W.B., Huang, J.Y., Hooley, G., Lynch, J. and Yau, O. (1992), "Effective Marketing in Taiwan: Profiles of the Top Performers," European Journal of Marketing, Vol. 26, No. 3 , pp. 5-17.

Mahoney, J.T. and Pandian, J.R. (1993), "The Resource-Based View within the Conversation of Strategic Management," Strategic Management Journal, Vol.1 3 , pp.363-380.

Mavondo, Felix T. (1999), "Environment and Strategy as Antecedents for Marketing; Effectiveness and Organizational Performance," Journal of Strategic Marketing, Vol.7, pp. 237-250.

Narver, John and Stanley Slater (1990), The Effect of Market Orientation on Business Profitability, Journal of Marketing, 54(October), 20-35. 
Norburn, D., Birley, S., Dunn, M.G. and Payne A. (1990), " A Four Nation Study of the Relationship Between Marketing Effectiveness and Business Performance," Journal of international Business Studies, vol. 21, pp. 451-468.

Oosthuizen, J.C. Jr. (1992), 'Marketing Effectiveness and Its Relationship to Organizational Culture Characteristics and Output Performance: the South African Experience," Joumal of Studies in Economics and Econometrics, Vol.16, No.1. pp.59-78.

Parasuraman, A. and Desphande, R. (1984), "The Culture Context of Marketing Management," in Belk, R.W. (Eds), AMA Educators' Proceedings, Series 50, American Marketing Association, Chicago, IL., pp.176-179.

Pelham, A.M. and D.T. Wilson, "A Longitudinal Study of the Impact of Market Structure, Strategy, and Market Orientation Culture on Dimensions of Small Firm Performance," Journal of the Academy of Marketing Science, vol 24, No. 1, pp.27-43.

Peters, T.J. and Waterman, R.H. (1982), In Search of Excellence: Lessons from America's Best-Run Companies, Harper \& Row, New York, NY.

Porter, Michael E.(1985), Competitive Advantage, New York: The Free Press.

Sin, Leo Y.M. and Alan C.M. Tse (2000), "How Does Marketing Effectiveness Mediate the Effect of Organizational Culture on Business Performance? The Case of Service Firms,' Journal of Services Marketing, Vol. 14, No. 4, pp.295-309.

Sinkula, J. (1994), "Market Information Processing and Organizational Learning," Journal of Marketing, Vol 58, No.1, pp.35-46.

Slater, Stanley F. and John C. Narver (1994), Does Competitive Environment Moderate the Market Orientation-Performance Relationship? Journal of Marketing, 58 (January), 46-55.

Sparling, Keith (1992), How to Evaluate and Improve Your Marketing Department, Chicago, Illinois: NTC Publishing Group.

Webster, Cynthia. (1993), Refinement of the Marketing Culture Scale and the Relationship Between Marketing Culture and Profitability of a Service Firm, Journal of Business Research, 26(February), 111-131.

Webster, Cynthia. (1995), Marketing Culture and Marketing Effectiveness in Service Firms, Journal of Services Marketing, 9 (2), 6-21.

Wilson, Aubrey (1993), Marketing Checklists, 2nd Ed., Berkshire, England, McGraw-Hill Yukselen, C. (1997), "Factors Associated with Marketing Effectiveness of Small and Medium Sized FDirms in Turkey," International Journal of Commerce and Management, Vol. 7, No.2, pp.99-105.

Zeithaml, V.A., A. Parasuraman and L.L. Berry (1985), "Problems and Strategies in Service Maarketing," Journal of Marketing, vol.49 (Spring), pp.33-46. 